\title{
TIME INDICES OF LONG-LATENT AUDITORY EVOKED POTENTIALS IN THE WORKERS OF "NOISE" PROFESSIONS AT THE PROCESS OF PREPARATION AND BOTILING OF NON-ALCOHOL AND WEAK ALCOHOL BEVERAGES
}

Shydlovska I.V., Shydlovska I.A., Shevtzova T.V., Volkova I.V. Hrechkivska H.V., Vavorovsky O.P., Brukhno R.P.
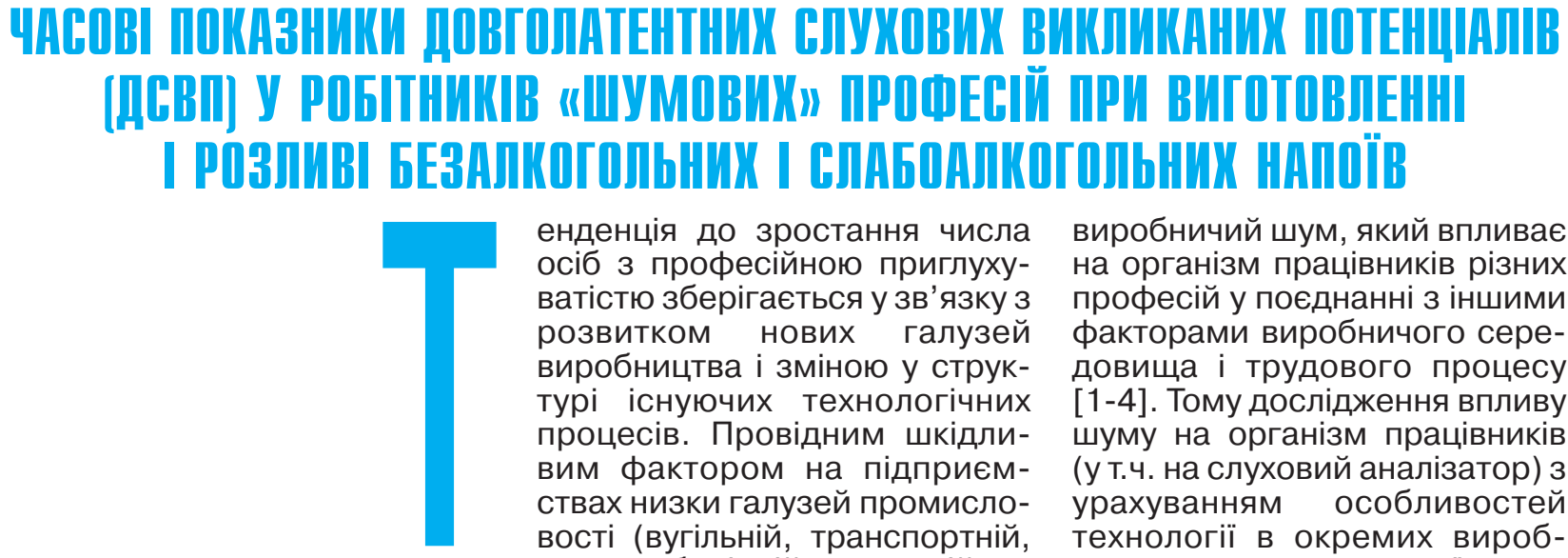

енденція до зростання числа осіб з професійною приглухуватістю зберігається у зв'язку 3 розвитком нових галузей виробництва і зміною у структурі існуючих технологічних процесів. Провідним шкідливим фактором на підприємствах низки галузей промисловості (вугільній, транспортній, машинобудівній, харчовій та ін.) залишається інтенсивний

виробничий шум, який впливає на організм працівників різних професій у поєднанні з іншими факторами виробничого середовища і трудового процесу [1-4]. Тому дослідження впливу шуму на організм працівників (у т.ч. на слуховий аналізатор) 3 урахуванням особливостей технології в окремих виробництвах є актуальними, їм присвячені численні роботи [5, 6].

Відомо, що тривала дія

1 ШИДЛОВСЬКА Т.В., 1 ШИДЛОВСЬКА Т.А. , 1ШЕВЦОВА Т.В., 1ВОЛКОВА Т.В., 2ГРЕЧКІВСЬКА Н.В., зЯВОРОВСЬКИЙ О.П., з БРУХНО Р.П.

1 ДУ «Інститут отоларингології ім. О.С. Коломійченка НАМНУ», 2Національна медична академія післядипломної освіти ім. П.Л. Шупика, ЗНМУ ім. О.О. Богомольця, м. Київ

УДК 613.644-052:612.85:663.8

Ключові слова: довголатентні слухові викликані потенціали, робітники «шумових» професій, корковий відділ слухового аналізатора. виробничого шуму не лише негативно впливає на слух, але й може викликати інші шкідливі наслідки. Зокрема, під впливом шуму можуть виникнути розлади центральної нервової і серцево-судинної систем. Також у результаті дії шуму високої інтенсивності можуть виникати зміни у нейроендокринній та імунній системах [2-5].

ВРЕМЕННЫЕ ПОКАЗАТЕЛИ ДЛИННОЛАТЕНТНЫХ СЛУХОВЫХ ВЫЗВАННЫХ ПОТЕНЦИАЛОВ (ДСВП) У РАБОЧИХ «ШУМОВЫХ» ПРОФЕССИЙ

ПРИ ИЗГОТОВЛЕНИИ И РАЗЛИВЕ

БЕЗАЛКОГОЛЬНЫХ И СЛАБОАЛКОГОЛЬНЫХ НАПИТКОВ

1'Шидловская Т.А., 1 Шидловская Т.В., 1 Шевцова Т.В., 1 Волкова Т.В., 2 Гречковская Н. В.,

3 Яворовский А.П., З Брухно Р.П.

1 ГУ «Институт отоларингологии

им. А.С. Коломийченко НАМН Украины», г. Киев

2 Национальная медицинская академия последипломного образования им. П.Л. Шупика, г. Киев

3 Национальный медицинский университет им. А.А. Богомольца, г. Киев

Цель данной работы - исследование функционального состояния коркового отдела слухового анализатора по данным длиннолатентных слуховых вызванных потенциалов (ДСВП) у рабочих «шумовых» профессий ПАО «Оболонь» с учетом гигиенических условий труда.

Материал и методы. Дана гигиеническая оценка шума, микроклимата и освещенности на рабочих местах операторов. Измерения проводились с помощью шумомера "Larson Davis 800B", шарового термометра «Тензор 41», кататермометра (F 564), люксметра типа Ю-116. Проведено исследование временных показателей ДСВП у 37 работников «шумовых» профессий ПАО «Оболонь» (в основном операторов по разливу напитков). Контрольная группа 15 соматически и отологически здоровых лиц, не имевших контакта с производственным шумом.
Результаты исследований. Установлено, что в соответствии с "Гигиенической классификацией труда...", утвержденной приказом Министерства здравохранения Украины № 248 от 08.04.2014 г., по уровням шума на отдельных рабочих местах условия труда операторов по разливу относятся $K$ классам условий труда 3.1 (вредные 1 степени) и 3.2 (вредные 2 степени); по показателям температуры воздуха - к классам условий труда 2 (допустимые), 3.1 (вредные 1 степени) и 3.2 (вредные 2 степени); по показателям тяжести и напряженности трудового процесса - к классам условий труда 2 (допустимые) и 3.1 (вредные 1 степени). В целом условия труда операторов по разливу относятся к классу вредности 3.2. (вредные 2 степени). При анализе ЛПП компонентов $P_{1}, N_{1}, P_{2}, N_{2}$ длиннолатентных слуховых вызванных потенциалов (ДСВП) при ипсилатеральной стимуляции тоном 1 кГц в основной группе по сравнению с контрольной выявлено достоверное $(P<0,01)$ удлинение ЛПП компонента $N_{2}$ ДСВП у рабочих «шумовых» профессий.

Выводы. У рабочих “шумовых» профессий ПАО «Оболонь», подвергающихся воздействию повышенных уровней постоянного широкополосного шума с превышением ГДР на средних и высоких частотах (500-8000 Гц), наблюдается достоверное $(P<0,01)$ удлинение ЛПП компонента $N_{2}$ ДСВП по сравнению с контрольной группой. Это свидетельствует о дисфункции корковых структур слухового анализатора у обследованных рабочих.

Ключевые слова: длиннолатентные слуховые вызванные потенциалы, рабочие «шумовых" профессий, корковый отдел слухового анализатора.

( Шидловська Т.В., Шидловська Т.А., Шевцова Т.В., Волкова Т.В., Гречківська Н.В.,

Яворовський О.П., Брухно Р.П. СТАТTЯ, 2016. 
Дослідження, проведені Т.А. Шидловською і Т.В. Шевцовою, показують, що вже на початкових стадіях розвитку професійної СНП в осіб, які працюють в умовах впливу виробничого шуму, страждає корковий відділ слухового аналізатора. Однак робіт, присвячених дії виробничого шуму на центральні структури слухового аналізатора, за даними довголатентних слухових викликаних потенціалів (ДСВП) у робітників шумових виробництв, недостатньо. Відсутні також дослідження щодо стану центральних відділів слухового аналізатора у робітників харчової промисловості, зокрема у робітників «шумових» професій підприємСтв з виготовлення і розливу безалкогольних та слабоалкогольних напоїв. Тому дослідження часових характеристик ДСВП у таких працівників $є$ доцільним і актуальним.

Не викликає сумніву і цінність методу реєстрації слухових викликаних потенціалів (коротколатентних та довголатентних) як об'єктивного тесту для оцінки функціонального стану коркових відділів слухового аналізатора.

Цей метод дозволяє достовірно виявити навіть незначні порушення у функціонуванні центральних відділів слухового аналізатора. Реєстрація довголатентних слухових викликаних потенціалів добре себе зарекомендувала у наукових дослідженнях та практичній медицині і широко використовується для оцінки функціонального стану коркового відділу слухового аналізатора і підкоркових його структур [5].

Мета даної роботи полягала у дослідженні функціонального стану коркового відділу слухового аналізатора за даними довголатентних (коркових) слухових викликаних потенціалів у робітників «шумових» професій ПАТ «Оболонь» 3 урахуванням гігієнічних умов праці.

Матеріал і методи. Гігієнічна оцінка умов праці операторів з розливу здійснювалася шляхом вимірювання рівнів шуму, параметрів мікроклімату, освітленості, оцінки умов праці за показниками важкості та напруженості праці.

Вимірювання рівнів шуму на робочих місцях проводили за Davis 800B". Температуру та відносну вологість повітря визначали за допомогою шарового термометра «Тензор 41», швидкість руху повітря кульковим кататермометром ( $F$ 564). Природне та штучне освітлення на робочих місцях працівників вимірювали за допомогою люксметра типу Ю-116.

Результати вимірювання рівнів шуму, параметрів мікроклімату, освітлення оцінювали відповідно до діючих державних санітарних норм.

Нами було проведено дослідження функції центральних відділів слухового аналізатора у 37 працівників «шумових» професій ПАТ «Оболонь», переважно в операторів з розливу напоїв. Контрольною групою слугували 15 соматично та отологічно здорових осіб, які не допомогою приладу "Larson

мали контакту з виробничим шумом.

Реєстрація довголатентних (коркових) слухових викликаних потенціалів проводилася 3 використанням загальноприйнятої методики за допомогою акустичної системи «Eclipse» фірми «Interacoustics». ДСВП реєстрували у відповідь на тональні посили тривалістю 300 мс, інтенсивністю 40 дБ над суб'єктивним порогом чутливості з частотою заповнення 1000 Гц та 4000 Гц (час зростання і спаду стимулу 20 мс). Частота імпульсів становила 500 Гц. Аналізували стандартну кількість вибірок (32), відповідь тривалістю 750 мс. Смуга пропускання фільтрів була у межах 2-20 Гц. Викликана електрична активність реєструвалась у відповідь на іпсилатеральне монауральне подання стимулу 3 частотою заповнення 1 кГц.

При аналізі отриманих кривих брали до уваги латентні періоди компонентів $\mathrm{P}_{1}, \mathrm{~N}_{1}, \mathrm{P}_{2} \mathrm{i}$ $\mathrm{N}_{2}$ ДСВП.

Результати та їх обговорення. На підприємствах з виготовлення та розливу безалкогольних та слабоалкогольних напоїв найчисельнішою категорією працівників, які зазнають дії шуму, є оператори з розливу напоїв.

Основним обладнанням, яке генерує шум у цехах з розливу напоїв, є конвеєрна лінія з розливу. Як показали наші дослідження, середній рівень шуму на лінії розливу у скляну тару становить $(87,83 \pm 0,89)$ дБА, у металічну банку - $(85 \pm 1,51)$ дБА, у пластикову тару -

Рисунок 2
Рисунок 1

Рівень звукового тиску (дБ) в октавних смугах $з$ середньогеометричними частотами (Гц) на лінії розливу у скляну тару

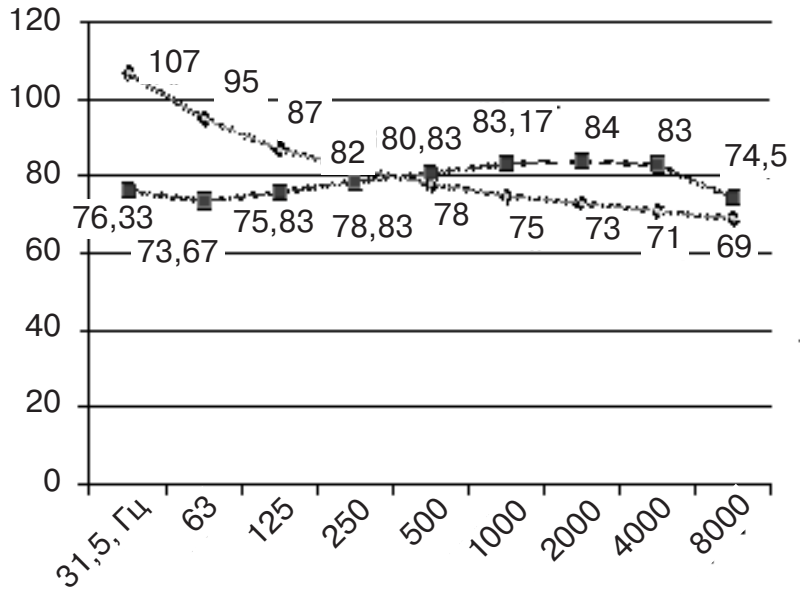

Рівень звукового тиску (дБ) в октавних смугах з середньогеометричними частотами (Гц) на лінії розливу у металеву тару
Примітка до рис. 1-3: $\diamond-$ нормативні показники;

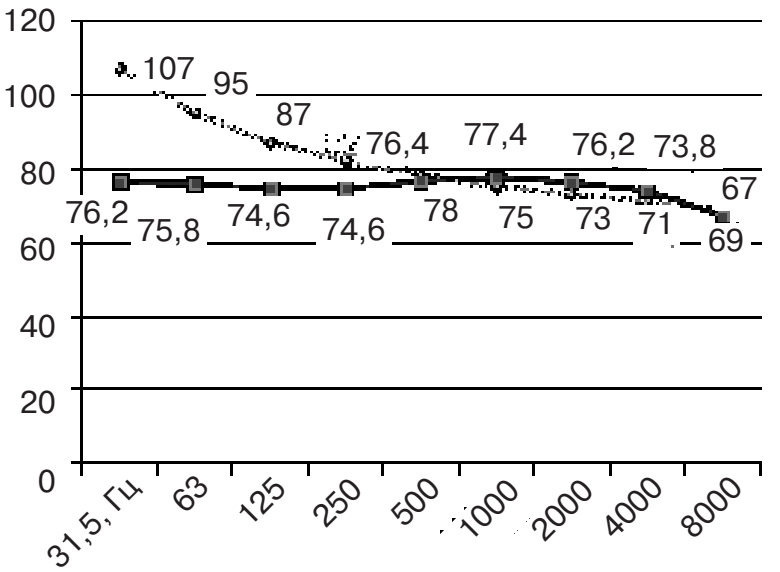

фактичні дані 
TIME INDICES OF LONG-LATENT AUDITORY EVOKED POTENTIALS IN THE WORKERS OF "NOISE" PROFESSIONS AT THE PROCESS OF PREPARATION AND BOTTLING OF NON-ALCOHOL AND WEAK ALCOHOL BEVERAGES

1Shydlovska T.V., 1 Shydlovska T.A., 1 Shevtzova T.V., ${ }^{1}$ Volkova T.V. ${ }^{2}$ Hrechkivska N.V., ${ }^{3}$ Yavorovsky O.P., ${ }^{3}$ Brukhno R.P.

1 State Institution «O.S. Kolomiichenko Institute of Otolaryngology", National Academy of Medical Sciences of Ukraine, Kyiv

${ }^{2}$ P. L. Shupyk National Medical Academy for Post-Graduate Education, Kyiv

${ }^{3}$ Bohomolets National Medical University, Kyiv

Objective. We studied the functional state of the acoustic analyzer cortex region by the data of longlatent auditory evoked potentials (LAEP) of the workers of "noise" professions, employed at the Obolon factory, taking into account the hygienic labour conditions.

Methods and materials. We present a hygienic assessment of noise, microclimate, and lighting on the working places of the operators. The measurements were performed with the help of audiometer "Larson Davis 800B", globe thermometer "Tensor 41", catathermometer (F 564), luxmeter "U-116". We carried out the study of temporary indices of long-latent auditory evoked potentials in 37 workers of "noise" professions at the Obolon factory (mainly the operators engaged in beverage bottling). The control group consisted of 15 somatically and otologically healthy people not affected the industrial noise.

Results. According to the "Hygienic Classification of
Labour..." № 248 of 08.04.2014, approved by the Decree of the Ministry of Public Health of Ukraine, by the noise levels at different working places the labour conditions of the workers, engaged in beverage bottling, may belong to 3.1 labour conditions class ( harmful conditions of the 1-st degree) and 3.2 class (harmful conditions of the 2-nd degree); by the temperature of the air - to 2 (permissible), 3.1 (harmful conditions of the 1-st degree) and 3.2 (harmful conditions of the 2-nd degree) labour conditions classes; by the labour process difficulty and its intensity - to 2 (permissible) and 3.1 (harmful conditions of the 1-st degree) labour conditions classes. As a whole the labour conditions of the operators, engaged in the beverage bottling, may be referred to the 3.2 danger class ( harmful conditions of the 2-nd degree). At the analysis of the peak latent periods of $P_{1}, N_{1}, P_{2}$ and $N_{2}$ components of the longlatent auditory evoked potentials under ipsilateral stimulation by $1 \mathrm{kHz}$ tone in the main group a reliable increase in length of the peak latent period of the $\mathrm{N}_{2}$ component in the workers of "noise" professions was detected in comparison with the control one.

Conclusions. A reliable $(P<0.01)$ increase in the length of the peak latent period of the $\mathrm{N}_{2}$ component of longlatent auditory evoked potentials was observed in the workers of "noise" professions at the Obolon factory, affected the increased levels of permanent, wide-range noise, exceeding MAL at medium and high frequencies (500-8000 Hz), in comparison with the control group. It testifies about a dysfunction of the cortex structures of the acoustic analyzer in examined workers.

Keywords: long-latent auditory evoked potentials, workers of "noise" professions, acoustic analyzer
$(86,6 \pm 1,3)$ дБА. Максимальний рівень шуму сягає 91 дБА. За своїми характеристиками шум постійний, широкосмуговий 3 перевищенням ГДР на середніх та високих частотах 500-8000 Гц. Час його впливу протягом усієї робочої зміни становив 6,5-7,5 годин.

Рівні звукового тиску (дБ) в октавних смугах 3 середньогеометричними частотами (Гц) на лініях розливу у скляну, металічну та пластикову тару наведено на рисунках 1-3.

Як видно з наведених результатів, на більшості робочих місць операторів з розливу рівень виробничого шуму перевищував допустимий на 111 дБА.

Додатковим чинником, який впливає на працівників, є нагріваючий мікроклімат у теплий період року. На робочих місцях на лінії розливу у металічну тару температура повітря становить $(28,1 \pm 0,9)-(31,9 \pm 1,37)^{\circ} \mathrm{C}$; на робочих місцях на лінії розливу у пластикову тару - $(26,73 \pm 0,61)$ $(27,73 \pm 0,45)^{\circ} \mathrm{C}$; на лінії розливу у скляну тару - $(22,7 \pm 0,91)-(22,9 \pm$ $0,56)^{\circ} \mathrm{C}$. Отже, температура повітря на окремих робочих місцях перевищувала допустимі значення у теплий період року на $0,7-4,9^{\circ} \mathrm{C}$. Відносна вологість повітря перевищувала норма- тивні величини на окремих робочих місць на 1-4\%. Швидкість руху повітря на усіх обстежених робочих місцях відповідала нормативним величинам. Показники освітленості на робочих місцях перебувають у межах нормативних величин.

Оцінка тяжкості і напруженості роботи показала, що оператори працюють у три зміни. Тривалість однієї зміни становить 8 годин. Кількість та тривалість перерв відповідають нормативним вимогам. До 70\% часу зміни робочі працюють стоячи. У вимушеній позі працівники перебувають до 12\% тривалості зміни (поза з нахилом тулуба вперед на 20-30). На більшості робочих місць працівники переміщують вантажі масою 1-2 кг. На окремих робочих місцях працівники піднімають та переміщують вантажі масою до 30 кг 5-10 разів протягом зміни і проходять 0,3-1 кM.

Таким чином, згідно з "Гігієнічною класифікацією праці за показниками шкідливості та небезпечності факторів виробничого середовища, важкості та напруженості трудового процесу", затвердженою наказом МO3 України № 248 від 08.04 2014 р., за рівнями шуму на окремих робочих місцях умови праці операторів 3 розливу належать до класів умов праці 3.1 (шкідливі 1 ступеня) та 3.2 (шкідливі 2 ступеня); за показниками температури повітря до класів умов праці 2 (допустимі), 3.1 (шкідливі 1 ступеня) та 3.2 (шкідливі 2 ступеня); за показниками важкості та напруженості трудового процесу - до класів умов праці 2 (допустимі) та 3.1 (шкідливі 1 ступеня). Загалом умови праці операторів 3 розливу належать до класу шкідливості 3.2. (шкідливі 2 ступеня).

Реєстрація дСВП з аналізом часових характеристик проводилась у робітників «шумових» професій $з$ початковими сенсоневральними порушеннями слухової функції. За даними суб'єктивної аудіометрії, в обстежених працівників було виявлене підвищення порогів слуху до тонів високочастотної ділянки конвенціонального діапазону частот (4-8) кГц та усіх частот досліджуваного розширеного діапазону частот (9-16 кГц). Обстежені оператори 3 розливу мали достовірно $(\mathrm{P}<0,01)$ підвищені пороги слуху на тони від 8 кГц до 16 кГц порівняно з особами контрольної групи. Так, у ділянці 8 кГц пороги слуху на тони в обстежених робітників становили 
$(19,86 \pm 3,99)$ дБ; 9 кГц $(36,78 \pm 3,39)$ дБ; 10 кГц $(38,22 \pm 4,35)$ дБ; 11 кГц $(49,68 \pm 5,89)$ дБ; 12 кГц $(52,95 \pm 3,75)$ дБ; 14 кГц $(55,92 \pm 3,46)$ дБ; 16 кГц $(60,18 \pm 4,92)$ дБ відповідно.

Часові показники ДСВП, які характеризують функціональний стан коркового відділу слухового аналізатора операторів, наведено у таблиці.

Як видно з даних таблиці, при порівнянні ЛПП компонентів $\mathrm{P}_{1}$, $\mathrm{N}_{1}$ ДСВП в умовах іпсилатеральної стимуляції тоном 1 кГц суттєвої різниці в основній групі порівняно з контрольною не відзначалося $(\mathrm{P}>0,05)$. Однак спостерігалося достовірне $(\mathrm{P}<0,01)$ подовження ЛПП компонента $\mathrm{N}_{2}$ ДСВП у робочих «шумових» професій.

Так, в основній групі ЛПП $\mathrm{N}_{2}$ ДСВП становив $(284,2 \pm 3,1)$ мс і був достовірно подовженим порівняно з контролем, де відповідне значення склало $(251,4 \pm 3,1)$ мс. Це свідчить про дисфункцію у коркових структурах слухового аналізатора у досліджуваних робітників, а також про втягнення у патологічний процес центральних відділів слухового аналізатора за дії виробничого шуму та інших факторів гігієнічних умов праці на їхніх робочих місцях.

Одержані нами дані узгоджуються 3 результатами, отриманими нами у попередній роботі (Т.В. Шидловська, Т.А. Шидловська), які встановили, що на ранніх стадіях розвитку порушень у слуховій системі за дії шуму зазвичай порушується сприйняття слуху на

\section{Рівень звукового тиску (дБ) в окт смугах з середньогеометричними частотами (Гц) на лінії розливу у пластикову тару \\ Рисунок 3 \\ вних}

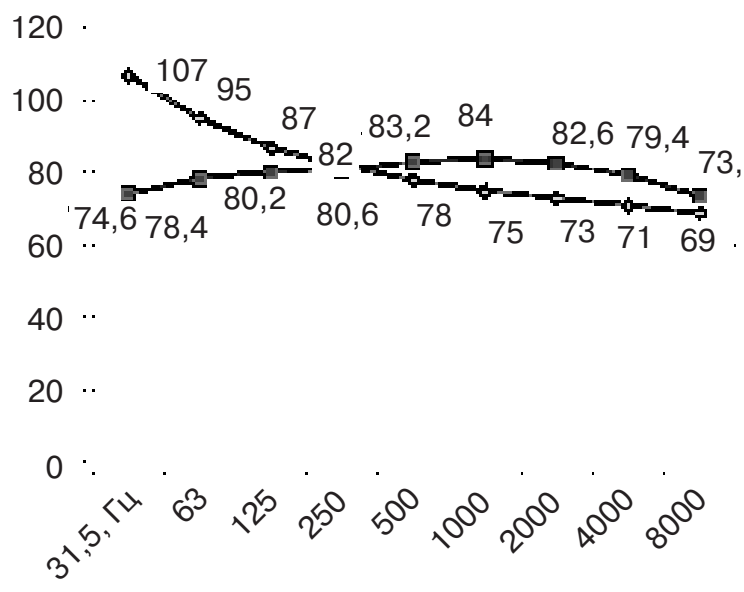
$\mathrm{N}_{2}$ ДСВП. ДСВП [5]. тони у ділянці 14-16 кГц високочастотного діапазону та ділянці 4-8 кГц конвенціонального, а також подовжується латентний період компонента

При більш тяжких формах, коли інтенсивність шуму, тривалість впливу або його певні характеристики обумовлюють подальший розвиток захворювання, до патологічного процесу залучаються також інші структури центральних відділів слухового аналізатора. 3 часом порушення тонального слуху стосуються частот мовного діапазону, з'являються ознаки ураження рецептора, а до процесу ураження залучаються і стовбуромозкові структури слухового аналізатора, про що свідчать подовжені часові характеристики КСВП, а також підкіркові, на що вказує збільшення ЛПП $\mathrm{P}_{2}$

1. Встановлено, що працівники «шумових» професій підприємства 3 виготовлення та розливу напоїв (оператори з розливу) зазнають комбінованого впливу виробничого шуму, несприятливого мікроклімату та несприятливих умов праці за показниками важкості та напруженості праці.

2. Провідним шкідливим фактором виробничого середовища операторів з розливу напоїв у скляну, пластикову і металеву тару є постійний широкосмуговий шум 3 перевищенням ГДР на середніх та високих частотах (500-8000 Гц). За рівнями шуму на окремих робочих міс-

Латентні періоди піків компонентів дСВП в осіб з СНП - робочих “шумових" професій (основна група) та в осіб контрольної групи при іпсілатеральній звуковій стимуляції тоном 1 кГц, $(\mathrm{M} \pm \mathrm{m})$

\begin{tabular}{|l|c|c|c|c|}
\hline \multirow{2}{*}{$\begin{array}{c}\text { Група } \\
\text { дослідження }\end{array}$} & \multicolumn{4}{|c|}{ ЛПП компонентів ДСВП, МС } \\
\cline { 2 - 5 } & $\mathrm{P}_{1}$ & $\mathrm{~N}_{1}$ & $\mathrm{P}_{2}$ & $\mathrm{~N}_{2}$ \\
\hline $\begin{array}{l}\text { Основна } \\
\text { група }\end{array}$ & $54,5 \pm 2,9$ & $115,8 \pm 3,2$ & $179,2 \pm 2,8$ & $284,2 \pm 3,1$ \\
\hline $\begin{array}{l}\text { Контрольна } \\
\text { група }\end{array}$ & $50,0 \pm 2,5$ & $112,9 \pm 2,7$ & $175,9 \pm 2,6$ & $251,4 \pm 3,1$ \\
\hline $\mathrm{t} \mid \mathrm{p}$ & $\begin{array}{c}1,18 \\
\mathrm{P}>0,05\end{array}$ & $\begin{array}{c}0,69 \\
\mathrm{P}>0,05\end{array}$ & $\begin{array}{c}0,86 \\
\mathrm{P}>0,05\end{array}$ & $\begin{array}{c}7,48 \\
\mathrm{P}<0,01\end{array}$ \\
\hline
\end{tabular}

Примітки: $t$ - коефіцієнт достовірності у групах; p>0,05 - недостовірна різниця між показниками в основній та контрольній групах; $p<0,01$ - достовірна різниця між показниками в основній та контрольній групах.

цях (перевищення допустимого рівня на 1-11 дБА) умови огераторів 3 розливу гольних напоїв належать до класів умов праці 3.1 (шкідливі 2 ступеня).

3. у робітників «шумових» професій ПАТ «Оболонь», за даними довголатентних слухо(ДСВП), спостерігається достовірне $(\mathrm{P}<0,01)$ подовження ЛПП компонента $\mathrm{N}_{2}$ ДСВП К Контрольною гру цію коркових структур слухового аналізатора в обстежених робітників, що, очевидно, плексу шкідливих та негативних чинників виробничого редовища.

і уточнюють наукові уявлення про патогенез професійної сенсоневральної приглухува- да дозоляють вирішува-

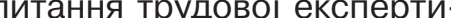
профілактичних заходів робітників «шумових» професій підприємств 3 виготовлення і

EPATYPA

робочих місцях і характеристика початкових порушень у слуків «шумових» професій авіаційного машинобудування / О.П. Яворовський, Т.В. ШидТ.В. Шевцова // Укр. журн, проблем медицини праці. 2008. - № 3 (5). - C. 63-70.

Таблиця 
2. Гігієна праці: підручник / Ю.І. Кундієв, О.П. Яворовський, А.М. Шевченко та ін.; за ред. Ю.І. Кундієва, О.П. Яворовського. - К. : Медицина, 2011. - 904 c.

3. Кундієв Ю.І. Професійна захворюваність в Україні у динаміці довгострокового спостереження / Ю.І. Кундієв, А.М. Нагорна // Укр. журнал 3 проблем медицини праці. 2005. - № 1. - С. 3-11.

4. Професійна приглухуватість шумової етіології (діагностика, класифікація, експертиза працездатності, профілактика): метод. рек. / за ред. Ю.І. Кундієва, Є.Г. Іванюка. К., 2001. - 30 c.

5. Шидловська Т.В. Сенсоневральна приглухуватість / Т.В. Шидловська, Д.І. Заболотний, Т.А. Шидловська. - К. : Логос, 2006. - 752 с.

6. Davoodi M. Noise-induced Hearing Loss / M. Davoodi // Intern. J. Occup. Environ. Med. - 2010. - Vol. 1 (3). - 146 p.

REFERENCES

1. Yavorovskyi O.P., Shydlovska T.V., Vertelenko M.V., Shevtsova T.V. Ukrainskyi zhurnal z problem medyzyny pratsi. 2008 ; 3 (5) : 63-70 (in Ukrainian).

2. Kundiev Yu.I., Yavorovskyi O.P., Shevchenko A.M. et al. Hihiiena pratsi : pidruchnyk [Occupational Hygiene : Manual]. Kyiv : Medytsyna; 2011: 904 p. (in Ukrainian)

3. Kundiev Yu.I.,

Nahorna A.M. Ukrainskyi zhurnal z problem medyzyny pratsi. 2005 ; 1 : 3-11 (in Ukrainian).

4. Kundiev Yu.I., Ivaniuk Ye.H. (eds.) Profesiina pryhlukhuvatist shumovoi etiolohii (diahnostyka, klasyfikatsiia, ekspertyza pratsezdatnosti, profilaktyka : metodychni rekomendatsii [Occupational Hypoacusis of Noise Etiology (Diagnosis, Classification, Working Ability Examination, Prevention) : Methodical Recommendations]. Kyiv; 2001 : 30 p. (in Ukrainian).

5. Shydlovska T.V., Zabolotnyi D.I., Shydlovska T.A.

Sensonevralna pryhlukhuvatist [Sensorineural Hypoacusis]. Kyiv : Lohos ; 2006 : 752 p. (in Ukrainian).

6. Davoodi M. Intern. J. Occup. Environ. Med. 2010 ; 1 (3) : 146.

Надійшло до редакціІ 14.09.2016

\section{ECOLOGICAL AND HYGIENIC DETERMINATION OF THE DETERIORATION OF POPULATION'S HEALTH IN THE INDUSTRIAL REGION}

Biletska E.M., Onul N.M., Holovkova T.A., Antonova O.V., Zemliakova T.D. ЕКОЛОГО-ГГГЕНПЧНА ДЕТЕРМПНОВННСТЬ ПОГІРШЕННЯ ЗДОРОВ'Я НАСЕЛЕННЯ ПРОМИСЛОВОГО РЕГІОНУ

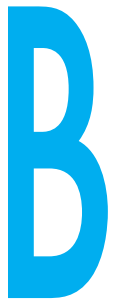

БІЛЕЦЬКА Е.М., ОНУЛ Н.М., ГОЛОВКОВА Т.А., АНТОНОВА О.В., ЗЕМЛЯКОВА Т.Д.

ДЗ «Дніпровська медична академія МОЗ України»

e-mail: enbelitska@ukr.net

Удк 504 : 614.78 : 369.066.42 : 711.454

Ключові слова: техногенне забруднення, мікроелементи, важкі метали, здоров'я, критичні групи населення, вплив. умовах техногенного пресингу на людину та середовище її проживання проблема здоров'я населення зросла до рангу національної безпеки країни. Адже згідно 3 резолюцією Генеральної Асамблеї ООН саме здоров'я населення визначається єдиним критерієм доцільності усіх без винятку сфер діяльності людського співтовариства [4, 8]. На жаль, здоров'я населення нашої країни перебуває у критичному стані за рівнем смертності та захворюваності, середньої очікуваної тривалості життя, що, разом 3 іншими чинниками, обумовлює депопуляцію населення країни $[5,6]$.

Нині масштабне антропогенне навантаження довкілля створило реальну небезпеку негативного впливу на здоров'я людини, який визначається переду-
ЭКОЛОГО-ГИГИЕНИЧЕСКАЯ ДЕТЕРМИНИРОВАННОСТЬ УХУДШЕНИЯ ЗДОРОВЬЯ НАСЕЛЕНИЯ ПРОМЫШЛЕННОГО РЕГИОНА Белецкая Э.Н., Онул Н.М., Головкова Т.А., Антонова О.В., Землякова Т.Д.

ГУ «Днепровская медицинская академия Министерства здравоохранения Украины»

На основе результатов более чем 20-летних исследований, проведенных на кафедре общей гигиены Днепровской медицинской академии, установлена значительная техногенная нагрузка ксенобиотиками организма человека в условиях промышленных территорий, свидетельством чему является превышение уровня содержания ксенобиотиков в биосубстратах в системе «мать-плод-ребенок» в 1,6-5,0 раз по сравнению с нормативным уровнем. При этом избыточное содержание ксенобиотиков в организме сочетается с дефицитом эссенциальных микроэлементов, что формирует вдвойне неблагоприятную ситуацию и подчеркивает потенциальную опасность даже малых концентраций токсикантов в окружающей среде для здоровья населения.

Установленные нарушения состояния здоровья населения с помощью разработанной нами биокинетической модели в системах "среда-организм-здоровье" и "мать-плод-ребенок" доказали их детерминированность мощным техногенным загрязнением жизнеобеспечивающих сред - атмосферного воздуха, питьевой воды, пищевых продуктов. Такое негативное состояние здоровья населения Днепровского региона научно обосновывает необходимость срочного внедрения управленческих мероприятий на государственном уровне социально-экономического, организационного, меди ко-профилактического характера на основе разработанной нами концептуальной модели управления риском развития экологически обусловленной патологии у населения промышленного региона. Ключевые слова: техногенное загрязнение, микроэлементы, тяжелые металлы, здоровье, критические группы населения, влияние.

() Білецька Е.М., Онул Н.М., Головкова Т.А., Антонова О.В., Землякова Т.Д. СТАТТЯ, 2016. 